simple, rapid, and readily available and thus may be especially suitable for hospital laboratories that do not have sophisticated typing facilities. It allows the early detection of epidemics and thus permits the concentration of infection control efforts.

\section{REFERENCES}

1. Blumberg HM, Rimland D, Kiehlbauch JA, Terry PM, Wachsmuth IK. Epidemiologic typing of Staphylococcus aureus by DNA restriction fragment length polymorphisms of rRNA genes: elucidation of the clonal nature of a group of bacteriophage-nontypeable, ciprofloxacin-resistant, methicillin-susceptible $S$ aureus isolates. J Clin Microbiol 1992;30:362-369.

2. Costas M, Cookson BD, Talsania HG, Owen RJ. Numerical analysis of electrophoretic protein patterns of methicillin-resistant strains of Staphylococcus aureus. J Clin Microbiol 1989;27:2574-2581.

3. Nicolle L, Bialkowska-Hobrzanska H, Romance L, Harry VS, Parker S. Clonal diversity of methicillin-resistant Staphylococcus aureus in an acute-care institution. Infect Control Hosp Epidemiol 1992;13:33-37.

4. Preheim L, Pitcher D, Owen R, Cookson B. Typing of methicillin resistant and susceptible Staphylococcus aureus strains by ribosomal RNA gene restriction patterns using a biotinylated probe. Eur J Clin Microbiol Infect Dis 1991;10:428-436.

5. Trilla A, Nettleman MD, Hollis RJ, Fredrickson M, Wenzel RP, Pfaller MA. Restriction endonuclease analysis of plasmid DNA from methicillin-resistant Staphylococcus aureus: clinical application over a three-year period. Infect Control Hosp Epidemiol 1993;14:29-35.
6. Wei MQ, Wang F, Grubb WB. Use of contour-clamped homogeneous electric field (CHEF) electrophoresis to type methicillin-resistant Staphylococcus aureus. J Med Microbiol 1992;36:172-176.

7. Giacca M, Menzo S, Trojan S, Monti-Bragadin C. Cluster analysis of antibiotic susceptibility patterns of clinical isolates as a tool in nosocomial infection surveillance. Eur J Epidemiol 1987;3:155-163.

8. Blanc DS, Lugeon L, Wenger A, Siegrist HH, Francioli P. Quantitative antibiogram typing using inhibition zone diameters compared with ribotyping for epidemiological typing of methicillin-resistant Staphylococcus aureus. I Clin Microbiol 1994;32:2505-2509.

9. Lugeon C, Blanc DS, Wenger A, Francioli P. Molecular epidemiology of methicillin-resistant Staphylococcus aureus at a low incidence hospital over a 4-year period. Infect Control Hosp Epidemiol 1995;16:260-267.

10. National Committee for Clinical Laboratory Standards. Performance standards for antimicrobial susceptibility testing. M2-A4. Villanova, PA: NCCLS; 1991.

11. Blanc DS, Siegrist HH, Sahli R, Francioli P. Ribotyping of Pseudomonas aeruginosa: discriminatory power and usefulness as a tool for epidemiological studies. J Clin Microbiol 1993;31:71-77.

12. Struelens MJ, Deplano A, Godard C, Maes N, Serruys E. Epidemiological typing and delineation of genetic relatedness of methicillin-resistant Staphylococcus aureus by macrorestriction analysis of genomic DNA by using pulsed-field electrophoresis. J Clin Microbiol 1992;30:2599-2605.

13. Tenover FC, Arbeit R, Archer G, et al. Comparison of traditional and molecular methods of typing isolates of Staphylococcus aureus. J Clin Microbiol 1994;32:407-415.

\title{
Drug-Resistant Acinetobacter baumanii
}

\section{Gina Pugliese, RN, MS} Martin S. Favero, PhD

Acinetobacter baumanii has been reported increasingly as a nosocomial pathogen worldwide, especially in outbreaks occurring in intensive-care units. This organism is a typical gramnegative water bacterium that has the fascinating ability to grow in all types of water and then to be distributed to environmental surfaces, some of which may become part of a colonization or infection route.

Dr. Xavier Corbella and coinvestigators from the University of Barcelona, Spain, evaluated fecal colonization with multidrug-resistant A baumanii in 189 consecutive patients admitted to three 12 -bed hos- pital intensive-care units (ICUs) during two different 2-month periods (October to November 1993 and May to June 1994). Rectal swabs were obtained from ICU patients on admission and weekly until discharge from the ICU. Overall, 77 (41\%) of 189 patients were found to be colonized with multidrug-resistant $A$ baumanii during the first week; 10 (13\%) during the second week; 9 (12\%) during the third week; and 3 (4\%) during the fourth to fifth weeks. Rectal swabs taken from 20 patients within the first 48 hours already were positive; 8 of these patients were admitted to the hospital from the community and did not have previous hospitalization, and 12 were from other wards of the hospital. Multidrug-resistant $A$ baumanii was isolated from 5 of 26 environmental samples (3 monitor touch pads, 1 ventilator tube, and 1 floor sample), as well as from 3 of 5 latex gloves worn by staff members who had been touching patients.

The authors conclude that the digestive tract in severely ill patients can be a reservoir for $A$ baumanii. In addition, the authors believe that the positive cultures of latex gloves worn by staff supports the relevance of cross-transmission of $A$ baumanii via gloved hands of staff.

FROM: Corbella X, Pujol M, Ayatts J, et al. Relevance of digestive tract colonization in the epidemiology of nosocomial infections due to multiresistant Acinetobacter baumanii. Clin Infect Dis 1996;23:329-334. 